\title{
O AMOR E O DIREITO PERTENCEM A \\ "IDIOMAS" DISTINTOS: UMA CRÍTICA À JURIDICIZAÇÃO DO AFETO
}

\author{
Doglas Cesar Lucas ${ }^{1}$ \\ Pâmela Copetti Ghisleni ${ }^{2}$
}

\section{LOVE AND LAW BELONG TO DIFFERENT "LANGUAGES": A CRITICAL TO JURIDICATION OF AFFECTION}

RESUMO: Este artigo problematiza o princípio da afetividade com base no argumento de que o discurso salvacionista do direito vem cometendo excessos na (vã) tentativa da regular os sentimentos e, neste caso específico, o afeto. É que se na sociedade pré-industrial a paternidade era um processo natural, a lógica industrial fez da vida como dádiva um acontecimento sensível à medicina, à pedagogia, à sociologia e ao direito, permitindo-se o planejamento de cada pequeno passo. Mas se agora ter um filho é um procedimento a ser calculado (apesar dos percalços do acaso), como se atreve o pai ou a mãe a não amar aquele ser? E mais, pode o direito fazer algo a respeito? A ciência jurídica recentemente vem fornecendo como resposta o princípio da afetividade, sob o argumento de que o abandono afetivo afronta a dignidade humana e a responsabilidade parental, posicionamento problematizado na presente pesquisa, a partir do emprego do método hipotéticodedutivo e da análise de jurisprudência.

Palavras-chave: Afeto. Direito. Família. Paternidade.
ABSTRACT: This article intends to problematize the principle of affectivity based on the argument that the Salvationist discourse of the law comes committing excesses in the (vain) attempt to regulate the feelings and, in this specific case, the affection. For if in pre-industrial society paternity was a natural process, industrial logic made life as a gift an event sensitive to medicine, pedagogy, sociology, and law, allowing for the planning of every small step. But if now having a child is a procedure to be calculated (despite the mishaps of chance), how dare the father or mother not to love that being? In addition, can the right do something about it? Legal science has recently been providing as a response the principle of affectivity, under the argument that affective abandonment faces human dignity and parental responsibility, a problematic position in the present research, using the hypothetical-deductive method and the analysis of jurisprudence.

Keywords: Affect. Right. Family. Paternity.

\footnotetext{
${ }^{1}$ Doutor em Direito pela UNISINOS e Pós-Doutor em Direito pela Università Degli Studi di Roma Tre. Professor dos Cursos de Graduação e de Mestrado em Direito da Universidade Regional do Noroeste do Estado do Rio Grande do Sul - UNIJUÍ e do Curso de Graduação em Direito do Instituto Cenecista de Ensino Superior Santo Ângelo - IESA. Professor colaborador do Curso de Mestrado e Doutorado em Direito da URI. Avaliador do INEP/MEC. doglasl@unijui.edu.br.

${ }^{2}$ Mestranda e Bolsista CAPES do Curso de Mestrado em Direitos Humanos da UNIJUí. pcghisleni@gmail.com.
} 


\section{CONSIDERAÇÕES INTRODUTÓRIAS}

Ya no se encantarán mis ojos en tus ojos, ya no se endulzará junto a ti mi dolor. Pero hacia donde vaya llevaré tu mirada y hacia donde camines llevarás mi dolor. Fui tuyo, fuiste mía. ¿Qué más? Juntos hicimos un recodo en la ruta donde el amor pasó.

(Pablo Neruda)

Quanto mais individualistas se tornam as sociedades (e as relações humanas), mais importância é atribuída ao amor como uma fonte suprema de felicidade, reconhecimento ou daquilo que Simon May (2012) denomina de enraizamento ontológico, ou seja, a incrível sensação de que tenho um lar que dá validade e solidez à minha existência. Essa nova dinâmica das relações logicamente vai repercutir nas instituições mais antigas (e talvez sólidas) que a humanidade foi capaz de engendrar, o casamento e a família, as quais desde então passam a se estruturar na ideia de amor, afeto e intimidade.

A descoberta da infância também foi fundamental para a introdução da afetividade nas relações familiares, pois agora o filho ganha contornos de sujeito, deixando de ser, finalmente, uma "coisa" dos pais. Nesta perspectiva, a prole reclama não somente atenção e cuidado, mas também e sobretudo o amor dos genitores como uma necessidade pedagógica e psicológica para seu próprio bem-estar e desenvolvimento. O direito endossa essa reivindicação por meio do princípio da afetividade e não raro tais demandas desaguam nos tribunais, suscitando dúvidas e controvérsias relativamente ao abandono afetivo parental, aqui compreendido como a ausência de interesse e de convivência afetiva do pai na relação com o filho ${ }^{3}$.

As demandas de indenização por abandono afetivo estão calcadas principalmente no princípio da dignidade da pessoa humana, preconizado pela Constituição Federal de

\footnotetext{
${ }^{3}$ Embora por diversas vezes mencionemos no presente artigo a expressão "pai", não se desconhece que o abandono afetivo pode ser protagonizado por qualquer um dos entes parentais. Por outro lado, a prática jurídica (por mais inadequada que possa ser) revela que na maioria dos casos o abandono afetivo é atribuído à figura paterna. Muitas vezes, esse próprio discurso oriundo das práticas jurídicas reforça as sectarizações de gênero, pois ele "[...] institui a atribuição de níveis valorativos à paternidade, classifica-a, nomeia-a, define seu lugar no arranjo familiar e sua importância na vida social" (PERUCCHI; TONELI, 2008, p. 146).
} 
1988, a qual foi responsável por uma verdadeira revolução na ordem jurídica, muitas das quais sequer os integrantes do Poder Constituinte mensuravam. Esta mudança transformou os anseios, valores e expectativas da sociedade, na medida em que, com a chamada Constituição Cidadã, o direito passa a preocupar-se com a figura mais vulnerável das relações, dentre as quais é possível citar a criança e o adolescente. Corolário lógico desta nova realidade é o fato de que não basta a prestação alimentar ou material. O afeto torna-se imprescindível e, neste ínterim, há uma (tentativa de) comunicação entre o direito e a psicanálise e, por mais bem intencionadas que sejam as investidas de dizer do afeto e do amor, talvez o direito não dê conta da tarefa de regular os sentimentos, tendo em vista todas as questões conscientes e inconscientes envolvidas.

Nesta perspectiva, é possível questionar-se sobre os limites do direito no que diz respeito à regulação da vida cotidiana: o direito tem algo (relevante) a dizer sobre o afeto? O legislador deve transformá-lo em um bem jurídico e em um valor a ser protegido? Não se duvida do fato de que uma relação afetuosa entre pais e filhos seja muito mais prazerosa e saudável ao desenvolvimento emocional da prole e também do adulto. Por outro lado, o afeto tem um quê de espontaneidade e inconsciente do qual talvez o direito não consiga se apropriar, a começar pelo fato de que provavelmente não há um cuidado efetivo sem afeto. Quer dizer, não se duvida também de que existe o dever intrínseco de cuidado parental, mas até que ponto impor o afeto não se constitui em uma violência?

Tais questões serão brevemente abordadas neste estudo, sem a pretensão de se esgotar o tema, até mesmo porque isso não seria possível em um artigo encabeçado apenas por juristas, havendo necessidade de contar com o imprescindível auxílio de outras áreas, como a psicologia e a psicanálise. O que se pretende, por conseguinte, é fomentar a reflexão acerca das limitações do direito que, cada vez mais, numa atitude que beira o narcisismo, se propõe a tudo regular e tudo dizer. Quanto aos objetivos gerais da pesquisa, optou-se pelo método exploratório. O critério de seleção dos três julgados relacionados ao tema será mencionado oportunamente, quando da análise dos casos. O artigo está dividido em três partes, iniciando-se pela abordagem acerca das transformações do amor e do afeto e seus reflexos na família. Após, discutem-se as possibilidades narrativas do 
direito moderno para, ao final, problematizar o princípio da afetividade a partir do decisionismo nos tribunais brasileiros.

\section{AS METAMORFOSES DO AMOR E SEUS REFLEXOS NA FAMÍLIA}

A presente seção inicia-se com alguns questionamentos intrigantes e cuja resposta dificilmente será encontrada, mas que justamente por isso se fazem necessários: por que o amor e o afeto se tornaram categorias tão fundamentais nas sociedades pós-industriais a ponto de atingir o sujeito em sua subjetividade e individualidade? Ou é o amor, do modo como conhecemos hoje, uma instituição ahistórica? "A vida só pode ser compreendida olhando-se para trás; mas só pode ser vivida olhando-se para frente". Se a conclusão (em parte clichê, é verdade) de Kierkegaard estiver certa, é imprescindível, antes de tudo, tecer algumas considerações sobre as transformações do amor ao longo da história, desde a Antiguidade até o mundo contemporâneo, a fim de que seja possível uma análise crítica a respeito de como tais metamorfoses repercutiram nas famílias.

A temática não é recente e as primeiras teorizações a respeito do amor de que se têm notícia remontam à filosofia grega clássica. "O Banquete", de Platão (428-347 a.C.), pode ser considerado como a primeira discussão extensa do tema na filosofia ocidental. Em resumo, a obra retrata o diálogo entre Fedro, Pausânias, Erixímaco, Aristófanes, Agatão, Alcebíades e Sócrates para comemorar o sucesso de Agatão em um concurso de poesias. Aristófanes faz menção ao mito da androginia, segundo o qual os seres humanos eram, a priori, completos, perfeitos, seres verdadeiramente esféricos ${ }^{4}$. Diante de sua autossuficiência, estes seres humanos que se julgavam perfeitos (homens, mulheres e hermafroditas) decidiram escalar o céu para desafiar os deuses do Olimpo, na tentativa de chegar à sua morada. Zeus, desgostoso com tamanha afronta, cinde os humanos em duas partes para que se tornem mais fracos, úteis e numerosos, condenando cada metade a vagar pelo mundo em busca da sua "tampa da panela", ou seja, da sua outra metade. Simbolicamente, estamos falando da busca do ser humano pelo encontro com sua alma gêmea, com aquele outro que me faz inteiro. O verdadeiro amor está no encontro com o

\footnotetext{
${ }^{4} \mathrm{~A}$ forma circular remetia aos deuses e à sua perfeição.
} 
outro que me completa. Para Aristófanes, o amor é justamente a busca constante e incansável pela outra metade a fim de se restabelecer o todo antes cindido e, justamente por isso, o amor, para o dramaturgo grego, se origina da perda. Estamos aqui, portanto, próximos do amor como paixão, do Eros. É o amor como desejo e esse desejo por alguma coisa não pode ser satisfeito, na medida em que amamos e desejamos justamente aquilo que não temos. Amor é desejo e desejo é falta. Por isso, quando o desejo, que se dá na falta, se satisfaz, o pretenso amor acaba.

Não menos importante na abordagem sobre o amor foi Aristóteles (384-322 a.C.), pois emprestou especial relevância ao amor encontrado na Philia, consistente na amizade entre os indivíduos iguais. Aqui, portanto, o afeto não tem a dimensão de ausência encontrada no Eros. Aristóteles concebeu três tipos de amizades, sendo que a amizade por prazer e por utilidade constituem as duas formas imperfeitas, ao contrário da amizade por virtude, que perfectibiliza a Philia como um atributo do homem bom.

\begin{abstract}
A amizade perfeita é a dos homens que são bons e afins na virtude, pois esses desejam igualmente bem um ao outro enquanto bons, e são bons em si mesmos. Ora, os que desejam bem aos seus amigos por eles mesmos são os verdadeiramente amigos, porque o fazem em razão da sua própria natureza e não acidentalmente. Por isso sua amizade dura enquanto são bons - e a bondade e uma coisa muito durável. E cada um e bom em si mesmo e para o seu amigo, pois os bons são bons em absoluto e úteis um ao outro. E da mesma forma são agradáveis, porquanto os bons o são tanto em si mesmos como um para o outro [...] (ARISTÓTELES, 1984, p. 181-182).
\end{abstract}

Assim, a terceira forma de amizade não é um meio de obtenção de algo (prazer ou vantagens), na medida em que é em si mesma uma finalidade, capaz de gerar virtude, intimidade e reciprocidade na presença. Logo, ela possui um caráter fundamental para o florescimento do ser humano, o que fez com que Aristóteles afirmasse que o homem realmente feliz (e bom) é aquele que possui amigos. Portanto, a Philia está ligeiramente ligada à felicidade e à bondade. Mas o homem bom transcende a noção de simples respeito a determinadas normas éticas. Ele se compromete em viver uma vida justa e com excelência de caráter. Por fim, o amor Ágape (ou Caritas), na concepção grega, designa o amor fraterno, o amor ao próximo. Ele traduz as ideias de solidariedade, de caridade e de amor em razão de uma humanidade comum. É um afeto que não pressupõe reciprocidade, 
na medida em que se estende e se prolonga até mesmo àqueles que não nos são íntimos. É, portanto, um amor doação.

Também são relevantes as contribuições feitas por Epicuro (341-270 a.C.) em sua "Carta sobre a Felicidade: a Meneceu". Para o filósofo, a felicidade e o bem último da vida humana deve ser o prazer, o que caracteriza sua filosofia como hedonista. Mas prazer em movimento e prazer em repouso são coisas (e sensações) distintas. Se o primeiro se manifesta na carne, causando excitação, o segundo é um bem supremo, um estado de equilíbrio. É deste último prazer de que fala Epicuro quando menciona que o sujeito deve desenvolver uma moral do prazer, que segundo ele, é uma propriedade do amor. É por essa razão que o prazer é o início e o fim de uma vida feliz. "Com efeito, nós o identificamos como o bem primeiro e inerente ao ser humano, em razão dele praticamos toda escolha e toda recusa [...]" (EPICURO, 2002, p. 37). Diante destas considerações, percebe-se que a filosofia grega, em boa medida, concebia o amor a partir de caracteres sexuais sublimados e generalizados, de modo que o amor transcende a existência humana materialmente considerada e adquire uma dimensão extramundana.

Na Idade Média, o cristianismo fortalece esta perspectiva de amor como algo que transcende a vida terrena. Nega-se a totalidade do ser enquanto entidade desejante e desejada e o sexo é apontado como luxúria, um dos sete pecados capitais. Assim compreendido, o corpo, em contraposição à mente, é o grande obstáculo na busca da perfeição espiritual que, por definição, é não sexual (e, portanto, não corporal) e transcende a carne (RICHARDS, 1993). Esta visão do cristianismo fez com que a Igreja regulasse o sexo inclusive no âmbito do casamento. Na realidade, o casamento configurase como o (único) espaço apropriado para a realização do amor, com o fim exclusivo de perpetuar a espécie. O fato é que o cristianismo, se por um lado castrou o sexo e o desejo, por outro elevou o amor a um patamar fundamental, o que ainda hoje tem resquícios muito profundos em nossa forma de amar, por mais contemporânea a emancipada que ela seja dos conceitos religiosos. Para May (2012, p. 119), está é “[...] a pedra fundamental de nossa profunda crença de que uma vida sem grande amor, seja dirigido a um amante romântico, a nossos filhos, a Deus, ou a um estranho necessitado, é empobrecida". 
E que consequências pode ter tido este fortalecimento de uma perspectiva metafísica do amor e das relações interpessoais, sobretudo para a família? Os casamentos eram arranjados e os pais manifestavam uma espécie de desinteresse em relação ao filho, já que o destino da descendência estava nas mãos de Deus. Além disso, acreditava-se que o amor e a paixão pecavam contra o matrimônio, no sentido de que amar e desejar a esposa em demasia, praticando com ela atos libidinosos que se dedicassem a outros fins que não a reprodução, acarretava uma instabilidade desnecessária (e danosa) à família tradicional da época. Portanto, o homem de inteligência razoável deve amar sua esposa com sensatez, e não com paixão (BECK; BECK-GERNSHEIM, 1998). Vivia-se, portanto, a tensão de corpos que exaltavam, por um lado, beleza e alegria e, por outro, ruína, culpa e perecimento (LE GOFF, 2005).

Se no medievo privilegiava-se uma espécie de amor Ágape atualizado, ao longo dos séculos XII e XIII consolida-se uma intensa transformação social que passa a valorizar a cortesia no trato com o outro. O l'amour courtois - fino, delicado e cheio de pompas - é ao mesmo tempo um sofrimento, protagonizado pelo cavalheiro que a tudo se submete e tudo faz pela sua dama. Se for preciso, o amante morre por amor, o que traduz o sucesso de inúmeros romances no Ocidente, a exemplo das tragédias amorosas envolvendo Tristão e Isolda - que no mesmo dia morrem de amor, ele por ela, ela por ele - e Guinevere e Lancelot. A tragédia do amor cortês, portanto, é o que o torna belo. É querer a unidade do amante, o encontro com o outro, e não poder realizá-lo. Por um lado, destaca-se o amorpaixão, no sentido de que o amante sofre pelo seu desejo irrealizável. Por outro, laiciza-se a mulher, objeto de amor, também inalcançável. "A mulher é cultuada agora como um repositório privilegiado de virtude, como inspirando em seu pretendente um amor que enobrece e confere virtude" (MAY, 2012, p. 163). Com base no francês Gaston Paris, John Moore (1979) elenca quatro características distintivas desta espécie de amor: (1) é ilegítimo e furtivo; (2) o amante ocupa um estrato social inferior e por isso é inseguro em relação à amada, que é colocada em um pedestal; (3) o amor da amada é conquistado mediante promessas e demonstração de valor e devoção; e (4) este amor é uma arte e uma ciência, sujeitando-se a determinadas regras, dentre as quais destaca-se a cortesia. Por conseguinte, o erotismo do amor cortês emerge justamente deste amor em suspensão 
(ou interrupção), irrealizável, impossível, cujo gozo, ainda que sensorial, não se dá no corpo.

Após o amor cortês, começa a se delinear o chamado amor romântico, reunindo vários dos elementos até aqui descritos. Consecutivamente à Revolução Francesa, a aventura amorosa agora é possível, tendo em vista que se enfraquece o sistema de casamentos arranjados (ROUDINESCO, 2003). Pouco a pouco, tornam-se inaceitáveis o casamento precoce (pré-pubertário) e o acasalamento entre homens e mulheres de gerações distintas. Nesta perspectiva, há uma tendência crescente de igualar o casal, privilegiando-se o amor em detrimento de quaisquer interesses outros de cunho utilitário. Essa ideia de amor romântico faz com que esposo e esposa se visualizem como colaboradores de um empreendimento emocional. Nele, o caráter sublime predomina sobre o ardor sexual típico do amor apaixonado, que do ponto de vista da ordem e do dever social, é sempre perigoso. Portanto, o homem tinha a prerrogativa de viver o amor apaixonado com a amante ou a prostituta, ao passo em que o romantic love destinava-se à consolidação de uma relacionamento prolongado no âmbito doméstico, nos termos de uma história compartilhada. Por isso, ele está amplamente relacionado à identidade, no sentido de que o outro integra (quando não completa) meu projeto reflexivo de constituição do eu (GIDDENS, 1993).

$\mathrm{Na}$ Modernidade, em contrapartida, uma nova forma de relação matrimonial começa a surgir. Já não são mais famílias que se unem, mas duas (e por que não mais?) pessoas que se amam e se elegem dentre as inúmeras possibilidades. A família, antes formada por um casamento de conveniência, agora assume uma relevante função na vida dos seus integrantes, não somente do ponto de vista privado, mas também no espaço público (FERRY, 2012). Essa nova percepção sobre o amor que surge entre o fim do século XIX e meados do século XX culmina em uma forma de organização familiar substancialmente diferente das suas predecessoras, caracterizada por três fenômenos centrais: (1) a revolução da afetividade, de modo que o casamento torna-se cada vez mais associado ao sentimento amoroso e à sexualidade masculina e feminina; (2) relevância atribuída ao filho que agora "maternaliza" (no sentido da "boa mãe") a família; e (3) a dissociação paulatina do desejo sexual da procriação, individualizando-se a célula familiar 
(ROUDINESCO, 2003). “A família moderna, ao contrário, separa-se do mundo e opõe à sociedade o grupo solitário dos pais e filhos" (ARIÈS, 1981, p. 189). Essa nova dinâmica das relações introduziu no cerne do casamento o amor, ante reservado aos amantes. Portanto, a família passa a funcionar sob a lógica do par, em que dois indivíduos se unem em busca de relações íntimas ou realização sexual e pessoal.

Ainda que o amor seja assim tão antigo como a humanidade, ainda que sempre seja ambivalente e venha acompanhado de seu contrario, o ódio, sua aparição na família moderna, o seja, o passo do casamento arranjado (o casamento por interesse) o casamento escolhido livremente por e para a plena realização do amor (em especial do amor pelos filhos) mudou nossas vidas [...] (FERRY, 2013, p. $15)^{5}$.

Nessa perspectiva, o amor dá sentido à vida e funda a família moderna, o que não significa que o afeto brote naturalmente no seio familiar. Se por um lado isso parece libertador, por outro implica em controle e fragilidade das relações. Há uma double face no processo de libertação, já que ele também "serve para condenar radicalmente todas as práticas ditas de 'fornicação' [...], assim como todas as relações carnais exteriores à conjugalidade" (ROUDINESCO, 2003, p. 97) ${ }^{6}$. A possibilidade de liberdade para decidir vem acompanhada da obrigação relativamente às exigências internalizadas do mercado. Nesse sentido, as alegrias da paternidade e da maternidade trazem consigo as dores do autossacrifício (BAUMAN, 2004). "Lo que antes se hacía sin preguntar, hoy hay que hablarlo, razonarlo, negociar y acordar y, justamente por ello, siempre puede ser anulado. Todo se vuelve 'discursivo'”' (BECK; BECK-GERNSHEIM, 1998, p. 18). A família industrial, então, deve ter sua libido canalizada para atividades produtivas, rentáveis, como a instrução ou a economia. Caso contrário, o caos e o apocalipse arruinariam a sociedade com uma abolição radical da diferença entre os sexos.

Ainda que aumentasse a procura por práticas contraceptivas, o infanticídio e o abandono permaneciam, na ocasião, como dois meios comuns para controle da

\footnotetext{
${ }^{5}$ No original: Aunque el amor sea sin duda tan antiguo como la humanidad, aunque siempre sea ambivalente y vaya acompañado de su contrario, el odio, su aparición en la familia moderna, es decir, el paso del matrimonio concertado (o matrimonio de interés) al matrimonio libremente elegido por y para la plena realización del amor (en especial del amor a los hijos) ha cambiado nuestras vidas [...]

${ }^{6}$ Em 2002 e 2006, George Bush, então presidente dos Estados Unidos, aumentou os investimentos em programas de abstinência sexual. (Ver: http://www.estadao.com.br/noticias/geral,governo-bush-amplia-programa-de-abstinenciasexual,20061103p65158. Acesso em: 08 jan. 2017).
} 
fecundidade. Isso evidencia que os filhos eram vistos, antes de tudo, como uma "coisa" dos pais. Essa realidade, contudo, muda na França a partir da Revolução e no restante da Europa no decorrer do século XIX. Com a redução da natalidade e as consequentes mudanças na dinâmica das famílias, "o filho deixava de ser uma coisa para se tornar, ele também, um sujeito integral" (ROUDINESCO, 2003, p. 99). Ele deixa de ser um acidente de percurso e torna-se um investimento na transmissão do patrimônio (de certo modo, continua sendo objeto, mas menos do que antes, pois agora é um ser desejado que responsabiliza o pai e a mãe).

Contemporaneamente, a internet (em uma óbvia aliança com o capitalismo) alterou substancialmente os contornos das relações interpessoais. De certo modo, ela revisita o antigo dualismo cartesiano que opôs mente e corpo, tendo em vista que é a mente o único local verdadeiro de pensamento e identidade (ILLOUZ, 2011). Este "processo de descrever a si mesmo baseia-se nos roteiros culturais da personalidade desejável" (ILLOUZ, 2011, p. 118). Se a linguagem tem um papel fundamental no mundo virtual, por outro (e ironicamente), o corpo assume posição de destaque e sedução, tudo por meio da fotografia de "perfil". Consequentemente, se o perfil psicológico que se destaca é o do indivíduo autêntico, que se diferencia da padronização e da repetição típicas da internet, a foto do perfil deve agregar uma espécie de convencionalidade estética. Eis a receita para ter sucesso na empreitada de romancear nas redes.

Outra grande modificação gerada pelo avanço da internet e das tecnologias referese aos aplicativos de conversação em tempo real, a exemplo do "WhatsApp" e dos seus rivais "Facebook Messenger", "Hangouts" e "ICQ". As possibilidades de controle são inúmeras. No "WhatsApp", por exemplo, o usuário tem acesso à ultima visualização dos seus contatos. O "check azul" informa que a mensagem enviada foi visualizada e, em alguns casos trágicos para os amantes em tempos de internet, não respondida. É possível ter privacidade e não ser vigiado constantemente? Sim, basta desativar tais comandos, mas ao caro preço de também não poder mais ter acesso aos dados por ele ocultados relativamente à sua lista de contatos. O controlador e controlado agora não é mais nem um, nem outro e, nesta perspectiva, talvez o aplicativo perca seu sentido. 
O fato é que a introdução da afetividade e do amor no seio familiar fez com que a família passasse "a desempenhar um papel ainda mais crucial para a constituição de novas narrativas da identidade, por estar na própria origem do eu e por ser aquilo de que ele precisava se libertar" (ILLOUZ, 2011, p. 16). As expectativas hoje são outras e, se há lugar para o amor, temos de admitir que há lugar também para a agressão e, talvez em uma projeção pior ainda, para a indiferença. É que esse amor moderno não se pode alcançar sem algumas contrapartidas amargas: decepção, ódio, rancor, amargura, tristeza. O fato de que os pais voltem todas as suas atenções para o filho constitui também uma exigência permanente para a criança. Ou seja, se antes o filho devia aos pais respeito e obediência, hoje a súplica cotidiana é por amor e, em contrapartida, os pequenos fornecem suporte emocional aos pais em meio ao mundo caótico e conturbado no qual vivem. O filho confronta o pai e a mãe com sua própria história de vida (BECK; BECK-GERNSHEIM, 1998).

Mas se o amor moderno é um sentimento que se fundamenta em si mesmo, ou seja, somente nos sujeitos que o vivenciam, então talvez "el no amar no es una infracción de las leyes, no es un acto criminal, aunque con ello se hiera la vida de otros más profundamente que con um robô o una lesión" (BECK; BECK-GERNSHEIM, 1998, p. 302). Logo, quem sacrifica o matrimônio, a família, a paternidade e, ao fim e ao cabo, o bem estar "dos seus", talvez não esteja cometendo crime ou pecado, pois está cumprindo a lei da autorrealização, mandamento primeiro da sociedade moderna. "El amor no se puede forzar", dirão Beck e Beck-Gernsheim (1998, p. 302). Por outro lado, alguns juristas advogam em prol do reconhecimento jurídico do princípio da afetividade, dentre os quais é possível citar Maria Berenice Dias $(2006)^{7}$, Paulo Lôbo ${ }^{8}$ (2011), Giselda Hironaka (2006) ${ }^{9}$ e

\footnotetext{
7 "Os laços de afeto e de solidariedade derivam da convivência familiar, não do sangue. Assim, a posse do estado de filho nada mais é do que o reconhecimento jurídico do afeto, com o claro objetivo de garantir a felicidade, como um direito a ser alcançado" (DIAS, 2006, p. 61).

8 "A afetividade é necessariamente presumida nas relações entre pais e filhos, ainda que na realidade da vida seja malferida, porque esse tipo de parentesco jamais se extingue" (LÔBO, 2002, p. 09).

9 "É certo que não se pode obrigar ninguém ao cumprimento do direito ao afeto, mas é verdade também que, se esse direito for maculado - desde que sejam respeitados certos pressupostos essenciais - seu titular pode sofrer as consequências do abandono afetivo e, por isso, poderá vir a lamentar-se em juízo, desde que a ausência ou omissão paternas tenham-Ihe causado repercussões prejudiciais, ou negativas, em sua esfera pessoal - material e psicológica repercussões estas que passam a ser consideradas, hoje em dia, como juridicamente relevantes" (HIRONAKA, 2006, pp. 18-19).
} 
Rodrigo da Cunha Pereira $(2011)^{10}$. Em linhas gerais, portanto, percebe-se que existem duas correntes doutrinárias no que diz respeito ao afeto como valor jurídico e a respectiva sanção a ser aplicada, quando for o caso. Um grupo defende que não é possível quantificar o afeto, justamente porque não há como obrigar ao amor. Outra corrente acredita que o afeto pode ser apreendido como um valor jurídico, dando ensejo ao princípio da afetividade. É sob este pano de fundo que se desenvolve a seção seguinte, destinada a tratar das possibilidades narrativas do direito moderno.

\section{O “FAZER JURÍDICO” CONTEMPORÂNEO: ENTRE LACUNA E EXCESSO}

A Modernidade caracterizou-se por um elogio à universalidade e à ideia de igualdade formal e abstrata. Essas grandes narrativas não mais bastaram, contudo, à compreensão do mundo pós-moderno, tornando cada vez mais patente a necessidade de problematizar, questionar e desconstruir a realidade posta e olhar para cada indivíduo a partir da sua existência singular e única. É que aquele homem resultado das revoluções liberais do século XVIII é um ser abstrato e, portanto, irreal, pois a partir do momento em que se introduzem experiências e características concretas na natureza humana, verificase que a igualdade e a dignidade preconizadas pelas declarações tornam-se quase que falaciosas.

É evidente que a sociedade sempre foi relativamente complexa e que a pluralidade de demandas sempre existiu, mas é preciso reconhecer que a contemporaneidade trouxe consigo uma série de (im)possibilidades à sociedade líquida a que se refere Bauman (2007). Com isso, não se trata mais somente do homem proletário, mas do homem que assume mil facetas e identidades e quer reconhecimento social, político e normativo para cada uma delas.

De fato, a Modernidade liberal é, nesse sentido, um momento paradoxal. Ao mesmo tempo em que prescreve a igualdade de todos perante a lei e institui um Estado legitimado pela convenção entre iguais, cria as condições para o

\footnotetext{
10 "Sem afeto não se pode dizer que há família. Ou, onde falta o afeto a família é uma desordem, ou mesmo uma desestrutura. É o 'afeto que conjuga'. E assim, o afeto ganhou status de valor jurídico e, consequentemente, logo foi elevado à categoria de princípio como resultado de uma construção histórica em que o discurso psicanalítico é um dos principais responsáveis, vez que o desejo e amor começam a ser vistos e considerados como verdadeiro sustento do laço conjugal e da família" (PEREIRA, 2011, p. 194).
} 
florescimento do ethos individual centrado na liberdade e na autonomia do sujeito, que ecoam nas diversas demandas de cunho individualista que o período vê eclodir [...] (SANTOS; LUCAS, 2015, p. 157).

Portanto, a complexidade passa a delinear uma ampla gama de formas de vida e estéticas existenciais. Se por um lado pluraliza-se a maneira de estar no mundo, ao mesmo tempo, individualiza-se ao máximo a história de vida do sujeito. Como consequência disso, diminuem os valores e convicções comuns que unificam a sociedade como um todo. Os espaços da vida anteriormente regulados por consensos implícitos agora sofrem constante questionamento. O que é uma vida boa de ser vivida? Isto é o sujeito quem vai determinar, e é desta maneira que ele vai viver (se quiser). Esta nova configuração tumultuada teve seus reflexos também no direito e, especialmente no contexto brasileiro, abriu caminhos, com a Constituição Federal de 1988, para a consolidação de outras fontes normativas que pudessem responder aos anseios da sociedade de maneira mais abrangente (e, por outro lado, nem sempre mais eficaz), haja vista a pluralidade de demandas. Mas o Estado, no seu intento salvacionista de tudo regular e tudo dizer, não tem conseguido barrar a inflação jurídica e legislativa oriunda de uma sociedade cada vez mais complexa, inquieta e fluída, acarretando aquilo que pode ser chamado de uma sobre-juridificação da realidade social (SOUZA SANTOS; MARQUES; PEDROSO, 1995). Nesta perspectiva, de diversificação de demandas, a lei engessada, positivada, parece não mais bastar para traduzir a resposta do direito aos anseios da sociedade. À normatização, resta assumir outras caras, com o que os princípios são elevados ao patamar de norma jurídica, fazendo do ordenamento legal um campo poroso, dúbio e muitas vezes incoerente.

A este fenômeno, Streck (2011) dá o nome de "pamprincipiologismo" ou "principiolatria", podendo ser traduzido como a fabricação de princípios despidos de normatividade quando da necessidade de resolver os chamados hard cases, teorizados principalmente por Dworkin (2010) e Hart (2009). Trata-se, portanto, de um discurso de cunho retórico-corretivo que está intimamente relacionado às práticas jurídicas brasileiras e cuja consequência é o uso desmedido de standards argumentativos que, não raro, são utilizados para burlar o que ficou decidido pela produção democrática (e constitucionalmente adequada) do direito, em termos de legislação. 
Estes acontecimentos relacionam-se intimamente com a nova hermenêutica constitucional - mais voltada para a linguagem e menos centrada no método - e com o neoconstitucionalismo, ambos os movimentos surgidos decorrer do século XX. Enquanto a hermenêutica clássica concebia os princípios gerais de direito como fontes alternativas, a nova hermenêutica valoriza a atuação do intérprete e da linguagem. Mas se benefícios importantes resultaram deste fenômeno interpretativo, esta nova hermenêutica possibilita um Poder Judiciário mais ativista, fazendo com que a segurança jurídica muitas vezes seja nocauteada pela atividade discricionária de alguns julgadores (ainda que em muitos casos as intenções sejam genuinamente boas).

É neste debate que se insere a discussão acerca do princípio da afetividade, pelo menos do ponto de vista defendido neste artigo, que se constitui em uma crítica à judicialização do afeto. O reconhecimento jurídico e a viabilidade científica deste princípio são questões não pacificadas na doutrina. De um lado, há os que o consideram uma decorrência da interpretação extensiva da ideia de dignidade da pessoa humana, consubstanciada no artigo 1ำ, inciso III, da Constituição Federal. É esta interpretação que tem possibilitado uma avalanche de decisões nos tribunais reconhecendo a existência do princípio da afetividade. A pergunta que aqui se coloca é sobre as reais possibilidades do Poder Judiciário ${ }^{11}$ - personificado na figura da Themis germânica vendada e, portanto, supostamente imparcial - de compreender as relações humanas a ponto de impor, no âmbito da família, o afeto? Pode o Magistrado apontar os erros de percurso dos pais e do filho, quantificando (e qualificando) afetos? Se Simon May (2012) estiver correto, e o amor, por si só, for insaciável, no sentido de que talvez nunca chegue um momento em que alcançaremos o amor satisfatório, o que fazer quando o afeto estiver presente e mesmo assim não for suficiente à demanda do outro? Pode o Estado transformar este sentimento tão íntimo e diversificado, do qual somente o ser que ama pode falar (BECK; BECK-GERNSHEIM, 1998), em um bem jurídico a ser tutelado? E mais, este mesmo Estado pode determinar que o afeto, quando ausente ou insuficiente, é passível de indenização?

\footnotetext{
${ }^{11} \mathrm{O}$ presente estudo optou por trabalhar com ênfase no Poder Judiciário tendo em vista que é o palco por excelência no qual se desenvolve a discussão envolvendo o princípio da afetividade, muito mais do que o Poder Legislativo.
} 
Para Illouz (2011, p. 09), “o afeto não é uma ação em si, mas é a energia interna que nos impele a agir, que confere um 'clima' ou uma 'coloração' particulares a um ato".

É prudente mencionar que os demais princípios constitucionais se espraiam na dimensão objetiva e externalizada dos relacionamentos sociais, e não nos elementos internos dos sujeitos, justamente porque o direito não dá conta de regular a afetividade, compreendida como um movimento de sensibilidade involuntário e inconsciente, para o qual sequer o próprio amante tem as explicações. É que ao contrário de outros meios de comunicação, o amor singularizou-se ao extremo a ponto de prescindir de qualquer argumentação. Ele se basta. Quem ama, ama porque sim, ama porque ama, e não precisa recorrer a nenhum outro critério para fundamentar esse amar ou a ausência de amor (LUHMANN, 1986). Disso resulta que da dignidade humana decorre, em termos, o princípio da afetividade. Em termos porque muitas vezes os afetos percorrem a órbita subjetiva em movimento exatamente contrário à dignidade humana de um dos envolvidos (eu tenho o direito de não amar, de não sentir afeto). Daí porque cai por terra a associação, pelo menos do ponto de vista imediato, entre princípio da afetividade e da dignidade da pessoa humana.

De fato, quando o direito e os tribunais não conseguem dar as respostas necessárias à pluralidade de demandas que Ihe são submetidas - as quais nem sempre podem ser resolvidas pelo método da subsunção, típico das regras -, os princípios parecem brotar de todos os lados, como se tivessem força normativa para tanto. Streck $(2011,2012)$ defende que princípios não são valores, e aí reside uma questão importante. Na sociedade pluralista contemporânea que perdeu boa parte das suas referências comuns, de modo que não existem mais crenças compartilhadas por todos, os valores muitas vezes são escolhas individuais ou produto da eleição dos membros da comunidade, mas agora levando em consideração a intersubjetividade. Nesta perspectiva, atribuir aos princípios a alcunha de "positivação de valores" implica em hierarquizar de forma absolutamente arbitrária quais valores efetivamente importam numa determinada sociedade ou num grupo.

Talvez seja necessário admitir que a questão do afeto, ao que tudo indica, está muito mais relacionada à moral do que ao direito, sobretudo contemporaneamente. $E$ 
ainda que ambas as categorias se relacionem, é errado afirmar que existe uma sobreposição entre elas. O direito é bilateral, coercivo, heterônomo e exterior. Já a moral é unilateral, autônoma, incoercível e interior.

Daí a necessidade de um combate hermenêutico à pamprincipiologia, que enfraquece sobremodo o caráter concretizador dos princípios, ao criar uma gama incontrolável de standards retóricos-persuasivos (na verdade, no mais das vezes, enunciados com pretensões performativas) que possibilitam a erupção de racionalidades judiciais ad hoc, com forte cunho discricionário (STRECK, 2012, p. 20).

$\mathrm{O}$ afeto não prêt-à-porter. A paternidade e a maternidade não fazem surgir no seio familiar um afeto genuíno e espontâneo. O afeto, como motivação interna que é, se movimenta na (in)consciência do sujeito, motivo pelo qual não pode ser enclausurado pelo direito por meio de exteriorizações como cuidado e carinho. O amor é coisa de quem ama e, por ser uma construção cultural, se dá na convivência. Ele vai do amante para o mundo e para o outro, e não o contrário. Talvez ninguém queira, em sã consciência, negar afeto, mas o fato é que o direito, por mais bem intencionado que seja, não consegue impô-lo a contragosto dos interessados e nem redirecioná-lo para outro objeto de desejo. Levado ao extremo, portanto, o princípio da afetividade faz com que a falta de sentimento seja um fato jurídico típico passível de indenização.

Neste ínterim, alguém poderia objetar que o princípio da afetividade favorece o surgimento de novas concepções de famílias (homoparentais, monoparentais, multiparentais, anaparentais, etc). Discorda-se. E a resposta é mais simples do que parece. Desejos, pulsões, sentimentos, emoções: estas (e muitas outras) são searas das quais o direito não deve (pode) se ocupar, a não ser que o faça no sentido de promover a autonomia privada do indivíduo, garantindo-lhe a liberdade de escolha a respeito do que ele compreende por família (e por amor). Dito de outro modo, o direito deve começar a acatar a contingência, a variabilidade e inclusive a irracionalidade, sob pena de tornar-se um discurso fechado e retrógrado que pisa no mesmo terreno do qual quis fugir a todo custo no passado. O direito, portanto, deve estar pronto para dar lugar à lei nenhuma (RODOTÀ, 2015). Nesse sentido, Warat (2000) afirma que em nossas sociedades o amor vem carregado de deveres, daí porque é burocrático e repressivo. “O capitalismo, para acomodar os indivíduos em seu proveito, impõe modelos de desejo. Assim circulam 
modelos de infância, de pai, de casamento, todos construídos em nome do dever e da verdade" (WARAT, 2000, p. 38).

Ocorre que, ao fim e ao cabo, o afeto não é princípio e nem valor jurídico. Que dirá um dever. É sentimento que se basta e prescinde de fundamentação. A crítica que se faz, portanto, não é à afetividade em si, muito menos à pluralidade de estéticas existenciais e familiares que o mundo oferece aos sujeitos. É evidente que uma família calcada na ideia de afeto, carinho, amor e cuidado tem mais probabilidade de se desenvolver de forma saudável e feliz, mas o princípio da afetividade é tudo, menos necessário, para regular tal situação. E por mais doído que seja o afeto não correspondido, os problemas, traumas e desilusões fazem parte da vida e, queira ou não, Ihe dão sentido existencial em um mundo caótico que reclama do sujeito cada vez mais individualidade.

Por fim, outra questão a ser levantada diz respeito à (des)patrimonialização do direito de família. O grupo de juristas que costuma defender o reconhecimento jurídico do princípio da afetividade - dentre os quais talvez Maria Berenice Dias (2006) seja a grande referência - afirma, geralmente sem grandes variações, que a despatrimonialização das relações pessoais possibilitou a compreensão do afeto como um elemento integrante das relações familiares. Mas se isto é verdade, é verdade também que esta mesma despatrimonialização a cargo de uma interpretação extensiva da dignidade humana fez com que este mesmo direito de família fosse patrimonializado, monetarizado, quantificado por meio de (às vezes "gordas") indenizações pela ausência de afeto. A família deixa de existir quando seus integrantes não se amam na medida que se espera deles? Tem menos validade a família que não está estruturada no afeto? Tais questões também serão brevemente ventiladas no item seguinte, o qual se destina à análise de julgados dos tribunais brasileiros em cujo cerne reside o princípio da afetividade.

\section{A (IN)CAPACIDADE DO DIREITO DIZER DO AMOR E DO AFETO: UMA CRÍTICA AO DECISIONISMO NOS TRIBUNAIS BRASILEIROS}

"Si hay que tener hijos, deben ser hijos deseados". Se Beck e Beck-Gernsheim (1998, p. 198) têm razão, não se admite mais, no âmbito de uma sociedade que fez da paternidade um método consciente e calculado, que um filho gerado não seja amado, não 
seja querido. Diante desta circunstância, aumentam as demandas de indenização por abandono afetivo, no sentido de que a falta de afeto implica em afronta ao patrimônio moral do filho. Ou seja, não basta o apoio material ou alimentar, tornando-se imprescindível para o salutar desenvolvimento psíquico e emocional do sujeito uma convivência calcada nos chamados deveres de afeto, que se exteriorizam no cuidado, no carinho, no abraço, no olhar.

A presente seção destina-se à análise da repercussão prática que tiveram tais mudanças de perspectiva relativamente ao amor e às novas narrativas do direito contemporâneo. No que diz respeito aos casos a serem analisados, cumpre fazer algumas considerações de cunho metodológico. É que a seleção de julgados levou em consideração três aspectos fundamentais. Primeiramente, o fato de que se objetivou colacionar (1) julgados recentes e (2) que retratassem o atual posicionamento majoritário adotado pelo respectivo tribunal. Além disso, optamos por selecionar julgamentos a cargo das (3) três instâncias distintas: Tribunal de Justiça do Estado do Rio Grande do Sul - escolha que se dá por uma questão geográfica -, Superior Tribunal de Justiça e Supremo Tribunal Federal. Por fim, é de ser mencionada a circunstância de que é esta pesquisa um artigo científico, o que embora permita algumas reflexões sobre a matéria, não possibilita uma análise minuciosa e profunda acerca dos posicionamentos adotados pelos tribunais brasileiros.

\section{1 "Amar é faculdade, cuidar é dever"}

E quando o cuidado extrapola a dimensão financeira, ou seja, o débito alimentar? É o caso do Recurso Especial no 1.159.242/SP ${ }^{12}$, julgado em 2012 e cuja decisão, protagonizada pela Ministra Relatora Nancy Andrighi, resultou na condenação do pai ao pagamento de duzentos mil reais para ressarcir o sofrimento da filha pelo abandono afetivo a que foi submetida. Ainda que o réu tenha adimplido a prestação alimentar até a maioridade da autora, foi condenado unicamente com base na (falta de) afetividade. Ou seja, o pai supostamente teria se omitido de cumprir com os deveres inerentes à

\footnotetext{
${ }^{12}$ REsp 1.159.242/SP, Rel. Ministra Nancy Andrighi, Terceira Turma, julgado em 24/04/2012, DJe 10/05/2012.
} 
paternidade, consubstanciados no que a Ministra Nancy Andrighi chama carinhosamente de "cuidado".

Embora seja louvável a decisão no sentido de reconhecer a importância dos laços de afetividade, o fato é que ela leva ao limite a discussão sobre as possibilidades de o Estado, na pessoa do julgador, interferir nas nuanças da vida privada. Isto porque cuidado e afeto são as duas faces de uma mesma moeda e, com isso, questiona-se: é possível cuidar sem afeto?

Embora tenha ares de objetiva, esta diferenciação entre afeto e cuidado é muito tênue, pois há uma relação quase que consequencial entre um e outro. Certamente este "cuidar" a que se refere a Ministra é bem diferente daquele que temos com o pedestre que atravessa a faixa da segurança ou com o idoso que adentra o estabelecimento bancário e para o qual eu educadamente seguro a porta giratória. Possivelmente ele transcende até mesmo a conduta descrita no art. 229 da Constituição Federal. Aquele é, sem dúvida, muito mais intenso, exigindo do eu uma entrega emocional constante, íntima, sincera. Além disso, se prolonga no tempo, e aí abrem-se as comportas para mais questionamentos envolvendo que qualidade de afeto queremos.

A autora do processo que logrou êxito na demanda talvez tenha incrementado sua conta bancária, mas a ferida pela ausência do pai possivelmente ainda esteja lá (talvez cicatrizando), refletindo-se nos erros e acertos de percurso da sua biografia. Com isso, pretende-se argumentar que alguns fatos não são passíveis de reparação. Conquanto seja possível indenizar, por exemplo, o filho pela perda do pai em acidente de trabalho ou de trânsito, o abandono afetivo talvez seja uma das dimensões mais subjetivas do direito, com o que se torna, se não impossível, ineficaz a postulada reparação.

\section{2 "Afeto não tem preço"}

O segundo julgamento escolhido para análise é oriundo da Sétima Câmara Cível do Tribunal de Justiça do Estado do Rio Grande do Sul, cujas recentes decisões têm manifestado um entendimento mais ou menos consolidado no sentido de que inexiste ato ilícito nos casos de abandono afetivo quando ausente comprovação acerca da omissão consciente do dever de cuidado. Assinala-se que embora o julgamento seja de 2010, as 
sábias palavras do Desembargador Sérgio Fernando de Vasconcellos Chaves, relativas à Apelação Cível no $70032449662^{13}$, têm sido amplamente reproduzidas nos recentes julgados do TJ-RS que versam sobre a matéria ${ }^{14}$.

No presente caso, o filho ajuizou ação de reparação civil em face do pai sob o argumento de que embora sempre tenha feito tudo que estava ao seu alcance para ser aceito, viu o genitor esquivar-se dos seus deveres paternos, motivo pelo qual requereu indenização por danos morais, além do pleito alimentar. O Relator, no auge de sua lucidez, entendeu que um pai pode ser compelido a cumprir deveres assistenciais, o que pode ser suprido jurisdicionalmente por meio de ações de paternidade, guarda e regulamentação de visitas, alimentos e execuções (e veja-se que tais demandas não retratam o dever de "cuidado", propriamente dito, descrito no julgado anteriormente analisado). Todavia, destacou que não há ação judicial capaz de fazer com que uma pessoa ame a outra ou desenvolva qualquer espécie de relação afetiva com alguém. E prossegue:

afinal o questionamento das raízes do afeto ou do amor, e da negação destes, leva a perquirir as razões íntimas do distanciamento havido entre pai e filho, que perpassam necessariamente às categorias do imanente e do transcendente, e implicam indébita invasão do campo jurídico ao terreno conceitual impreciso que avança pelo mundo da medicina, da biologia e da psicologia (RIO GRANDE DO SUL, 2010).

Este posicionamento reforça aquilo que já foi dito ao longo do artigo no sentido de que talvez o direito não tenha absolutamente nada a dizer sobre o afeto. Também nos recorda de que existe um certo grau de sofrimento que é inerente à nossa condição humana, tão mundana, frágil e efêmera (FREUD, 2010), mas justamente por ser "nossa", é tudo o que temos, e é por isso que apostamos tanto em nossas relações afetivas e amorosas, projetando nelas categorias como reconhecimento, identidade e felicidade (ILLOUZ, 2016), típicas da contemporaneidade.

A moral é que o amor, em contraposição ao zelo, à devoção e à proteção, não pode, nem em princípio, ser igual, ou universal, ou incondicional. E que embora os filhos, com sua aguda sensibilidade à diferença entre zelo e amor, façam todo o possível para tentar evocar amor em seus pais quando ele não está naturalmente presente, eles fracassarão (MAY, 2012, p. 327)

\footnotetext{
${ }^{13}$ Apelação Cível № 70032449662, Sétima Câmara Cível, Tribunal de Justiça do RS, Relator: Sérgio Fernando de Vasconcellos Chaves, Julgado em 26/05/2010.

${ }^{14}$ Dos quais são exemplos os casos das apelações cíveis nos 70071196729, 70069644805, 70067720235 e 70068797851, todas publicadas no Diário Oficial em 2016.
} 
Compreende-se e solidariza-se com os motivos pelos quais demandas reivindicando afeto chegam aos tribunais. Mas acredita-se que não há valor econômico capaz de restituir o beijo não dado, o abraço dispensado, o olhar carinhoso não retribuído, o vínculo amoroso não cultivado. De fato, talvez o afeto não tenha preço e, nesta perspectiva, quantificá-lo é no mínimo ilusório.

\subsection{Ter afeto (e ser feliz) é constitucional}

Como se já não bastasse a invocação do "sobreprincípio" da afetividade, os tribunais superiores têm recorrido também ao que o Ministro Celso de Mello chama de "princípio constitucional da busca da felicidade" ${ }^{15}$. É o caso da paradigmática decisão proferida no Recurso Extraordinário no $898060 / \mathrm{SC}^{16}$ que, na prática, reconheceu a possibilidade jurídica da multiparentalidade. O pai biológico interpôs o recurso em face de decisão do Tribunal de Justiça de Santa Catarina que estabeleceu responsabilidades ao genitor, dentre as quais se inclui o pagamento de alimentos, apesar da presença do pai afetivo. A discussão, portanto, girava em torno da (im)possibilidade de reconhecimento da dupla paternidade e da prevalência da paternidade socioafetiva sobre a biológica. O Relator Luiz Fux concluiu que "a paternidade socioafetiva, declarada ou não em registro público, não impede o reconhecimento do vínculo de filiação concomitante baseado na origem biológica" (BRASIL, 2016), de modo que daí derivam todas as consequências patrimoniais e extrapatrimoniais que já conhecemos.

É indubitável que a decisão tem um grande mérito: o reconhecimento de novas possibilidades no seio das relações familiares, de modo que possivelmente trará a dita felicidade às partes do processo. Mas novamente a principiolatria a que se refere Streck (2011) parece bater à porta do edifício jurídico: que necessidade é essa do ser humano ter um direito à busca da felicidade? Como se já não bastasse o simples fato de existir. 0 direito não precisa autorizar (ou obrigar) ninguém a ser afetuoso, assim como não faz

\footnotetext{
${ }^{15}$ RE 477.554-AgR, Rel. Min. Celso de Mello, DJe de 26/08/2011.

${ }^{16}$ Recurso Extraordinário no 898.060/SC, Supremo Tribunal Federal, Relator: Ministro Luiz Fux, Julgado em $21 / 09 / 2016$.
} 
sentido ele dizer que o sujeito tem direito à busca da felicidade. Para quem gosta de perfumaria, a ideia de um princípio constitucional do direito à busca da felicidade até pode agradar, mas sabendo que o conceito de felicidade é absolutamente subjetivo, relativo e depende de uma série de condições materiais (que muitas vezes o próprio Estado sequer proporciona minimamente, a exemplo dos direitos sociais), não há como defender esta fabricação desenfreada de princípios. Nos dizeres de Warat (1990, p. 98), "as palavras precisam valer tanto mais como intensidades que como elos conceituais".

Para o Ministro Relator, "o direito à busca da felicidade funciona como um escudo do ser humano em face de tentativas do Estado de enquadrar a sua realidade familiar em modelos pré-concebidos pela lei" (BRASIL, 2016). O curioso é que determinar que o afeto é inerente às relações familiares talvez também seja uma maneira de enquadrar a realidade familiar num modelo ditado pela lei (ou pelos tribunais) ${ }^{17}$. Uma coisa é determinar um conceito coletivo de justiça. Outra bem diferente é precisar estes mesmos limites para categorias tão subjetivas como felicidade e afeto.

\section{CONSIDERAÇÕES FINAIS}

A título de considerações finais, é possível destacar que a ideia de princípio da afetividade relaciona-se intrinsecamente com três temas centrais: o reconhecimento jurídico da união entre pessoas do mesmo sexo, a reparação financeira em razão de abandono afetivo e, por fim, o reconhecimento jurídico da multiparentalidade. A crítica deste estudo dirigiu-se à segunda consequência, consubstanciada na monetarização das relações interpessoais e, não bastasse isso, arriscamo-nos a dizer que invocar um princípio da afetividade não seria necessário para tutelar a união homoafetiva e nem a multiparentalidade.

Outra questão levantada diz respeito a até que ponto o princípio da afetividade não reproduz as sectarizações típicas do machismo? Por que a mãe, que gesta, concebe e

\footnotetext{
${ }^{17}$ E aqui cabe mencionar o caso das relações homossexuais. Por que utilizar o termo homoafetividade, como se não fosse possível inserir no seio de relações entre pessoas do mesmo sexo a dinâmica do ato sexual? Parece uma imposição, decorrente do princípio da afetividade, o fato de que as novas formas familiares devam ser, elas também, calcadas no ideal do afeto. A verdade é que tais famílias devem ter como base aquilo que efetivamente as sustente, seja o amor, o afeto, a sexualidade ou a conveniência, não cabendo ao Estado ditar as regras a respeito de quais formas e fundamentos são válidos e quais não são.
} 
amamenta, é o sujeito não questionado nos tribunais? É evidente que a natureza e sua dinâmica faz com que a mãe fique aprisionada à prole. Mas se por um lado as demandas levadas ao Poder Judiciário escancaram a situação difícil pelas quais muitas mulheres passam por terem de criar e dar suporte aos filhos por si próprias, sem contar com o auxílio do pai, por outro, elucida que talvez o princípio da afetividade reforce uma dimensão machista do direito, ao deixar implícito que o afeto e o amor seriam quase que inerentes à figura da mãe, revisitando a clássica, clichê e falaciosa figura do instinto maternal. E quando existir abandono afetivo inverso, ou seja, dos filhos em relação aos pais? O princípio da afetividade estaria a reforçar, aliado ao art. 229 da Constituição Federal de 1988, uma possível indenização para ressarcimento pelos danos sofridos?

Por conseguinte, acredita-se que, pelo menos do ponto de vista da técnica jurídica, o princípio da afetividade não tem viabilidade científica. Até mesmo porque, apesar do Projeto de Lei no 700 de 2007, inexiste, até o momento, legislação específica no ordenamento jurídico que trate expressamente da questão do abandono afetivo ${ }^{18}$. E ainda que houvesse legislação tratando da matéria, acredita-se que, por melhores que sejam as intenções, a inclusão expressa do princípio da afetividade no corpo constitucional limita-se a trazer riqueza do ponto de vista conceitual e gramatical, mas não substancial. É um direito que diz o óbvio. E deste direito, talvez não precisemos.

O problema que se coloca, na verdade, é também sobre os limites. Não demora muito e talvez os tribunais sejam palcos de demandas por indenizações por abandono afetivo dos cônjuges (sendo que o direito extirpou a culpa do direito de família em 2010 com a EC 66). O que fariam, na sociedade contemporânea, os trágicos amantes não correspondidos do amor-cortês? Talvez ainda existam alguns pipocando entre nós, aqui e acolá, mas é pouco crível que eles postulariam em juízo o ressarcimento pelo amor não correspondido do amado ou da amada, provavelmente com base no fato de que o amor, por si só, é insubstituível e não pode ser forçado. O amor-cortês, intenso e guloso que é, não se contenta com as migalhas, com os restos, com o bagaço da laranja. Nós

\footnotetext{
${ }^{18}$ O projeto propõe a alteração da Lei no 8.069/1990 (Estatuto da Criança e do Adolescente) para caracterizar o abandono moral como ilícito civil e penal. Disponível em: http://www25.senado.leg.br/web/atividade/materias/Lmateria/83516. Acesso em: 08 mar. 2017.
} 
contemporâneos, que tanto queremos do mundo, da vida e dos outros, quiçá devêssemos fazer a mesma coisa. Ou não, mas aí seriamos obrigados a concordar com Nelson Rodrigues e admitir que "o dinheiro compra tudo, até amor verdadeiro".

\section{口a}

\section{REFERÊNCIAS}

ARIÈS, Philippe. História social da criança e da família. Tradução de Dora Flaksman. Rio de Janeiro: Livros Técnicos e Científicos Ed., 1981.

ARISTOTELES. Ética a Nicômaco. In: Coleção Os Pensadores. São Paulo: Abril Cultural, 1984.

BAUMAN, Zygmunt. Amor líquido: sobre a fragilidade dos laços humanos. Tradução de Carlos Alberto Medeiros. Rio de Janeiro: Zahar, 2004.

BAUMAN, Zygmunt. Tempos líquidos. Tradução de Carlos Alberto Medeiros. Rio de Janeiro: Zahar, 2007.

BECK, Ulrich; BECK-GERNSHEIM, Elisabeth. EI normal caos del amor. Barcelona: El Roure Ed., 1998.

BRASIL. Superior Tribunal de Justiça. Acórdão no Recurso Especial no 1.159.241/SP. Relator: ANDRIGHI, Nancy. Publicado no DJ de 10-05-2012. Disponível em: <https://ww2.stj.jus.br/processo/pesquisa/?src=1.1.2\&aplicacao=processos.ea\&tipoPesqui sa=tipoPesquisaGenerica\&num_registro=200901937019>. Acesso em: 26 jan. 2017.

BRASIL. Supremo Tribunal Federal. Acórdão no Recurso Extraordinário no 898.060/SC. Relator: FUX, Luiz. Publicado no DJ de 30-09-2016. Disponível em: <http://www.stf.jus.br/portal/processo/verProcessoAndamento.asp?numero $=898060 \&$ cla sse=RE\&origem=AP\&recurso=0\&tipoJulgamento=M>. Acesso em: 26 jan. 2017.

DIAS, Maria Berenice. União homoafetiva. 3. ed. São Paulo: Revista dos Tribunais, 2006.

DWORKIN, Ronald. Levando os direitos a sério. São Paulo: WMF Martins Fontes, 2010.

EPICURO. Carta sobre a felicidade: a Meneceu. Tradução de Álvaro Lorencini e Enzo Del Carratore. São Paulo: Ed. UNESP, 2002.

FERRY, Luc. A revolução do amor: por uma espiritualidade laica. Tradução de Véra Lucia dos Reis. Rio de Janeiro: Objetiva, 2012.

FERRY, Luc. Sobre el amor: una filosofia para el siglo XXI. Buenos Aires: Paidós, 2013.

FREUD, Sigmund. 0 mal-estar na civilização, novas conferências introdutórias à psicanálise e outros textos (1930-1936). Tradução de Paulo César de Souza. São Paulo: Companhia das Letras, 2010. 
HART, Herbert Lionel Adolphus. O conceito de direito. São Paulo: WMF Martins Fontes, 2009.

HIRONAKA, Giselda Maria Fernandes Novaes. Os contornos jurídicos da responsabilidade afetiva na relação entre pais e filhos: além da obrigação legal de caráter material, 2006. Disponível em: <http://www.egov.ufsc.br/portal/sites/default/files/anexos/32839-407541-PB.pdf>. Acesso em: 17 abr. 2017.

ILLOUZ, Eva. O amor nos tempos do capitalismo. Tradução de Vera Ribeiro. Rio de Janeiro: Zahar, 2011.

ILLOUZ, Eva. Por qué duele el amor? Una explicación sociológica. Buenos Aires: Katz Editores, 2016.

LE GOFF, Jacques; TRUONG, Nicolas. Una historia del cuerpo en la edad media. Barcelona: Paidós, 2005.

LÔBO, Paulo Luiz Netto. Entidades familiares constitucionalizadas: para além do numerus clausus. Revista Brasileira de Direito de Família, Porto Alegre: Síntese, n.12, jan./mar.2002. Disponível em: <http://www.ibdfam.org.br/_img/congressos/anais/193.pdf>. Acesso em: 14 abr. 2017.

LUHMANN, Niklas. Love as passion. Traduzido por Jeremy Gaines e Doris L. Jones. Massachusetts: Harvard University Press, 1986.

MAY, Simon. Amor: uma história. Tradução de Maria Luiza X. de A. Borges. Rio de Janeiro: Zahar, 2012.

MOORE, John. Courtly love: a problem of terminology. Journal of the History of Ideas. Vol. 40. n. 40, (Out.-Dez., 1979). Disponível em: <http://faculty.winthrop.edu/kosterj/engl512/readings/moorecourtlylove.pdf>. Acesso em: 20 jan. 2017.

PEREIRA, Rodrigo da Cunha. Princípio da afetividade. In: DIAS, Maria Berenice (Org.). Diversidade sexual e direito homoafetivo. São Paulo: Revista dos Tribunais, 2011.

PERUCCHI, Juliana; TONELI, Maria Juracy Filgueiras. Aspectos políticos da normalização da paternidade pelo discurso jurídico brasileiro. Revista Associação Brasileira de Psicologia Política, São Paulo, v. 8, n. 15, p. 139-156, jun. 2008. Disponível em: $<$ http://pepsic.bvsalud.org/scielo.php?script=sci_arttext\&pid=S1519549X2008000100010\&lng=pt\&nrm=iso>. Acesso em: 07 mar. 2017.

PLATÃO. Diálogos: o banquete. Tradução de José Cavalcante de Souza. São Paulo: Difusão Européia do Livro, 1972.

RICHARDS, Jeffrey. Sexo, desvio e danação. As minorias na idade média. Tradução de Marco Antonio Esteves da Rocha e Renato Aguiar. Rio de Janeiro: Jorge Zahar, 1993.

RIO GRANDE DO SUL. Tribunal de Justiça do Estado do Rio Grande do Sul. Acórdão na Apelação Cível no 70032449662. Relator: CHAVES, Sérgio Fernando de Vasconcellos. Publicado no DJ de 04-06-2010. Disponível em: <http://www1.tjrs.jus.br/site_php/consulta/consulta_processo.php?nome_comarca=Tribu 
nal+de+Justi\%E7a\&versao=\&versao_fonetica=1\&tipo=1\&id_comarca=700\&num_processo _mask=70032449662\&num_processo $=70032449662 \&$ codEmenta $=3544259 \&$ tem IntTeor $=\mathrm{t}$ rue>. Acesso em: 26 jan. 2017.

RODOTÀ, Stefano. Diritto d'amore. Bari: Laterza, 2015.

SANTOS, André Leonardo Copetti; LUCAS, Doglas Cesar. A (in)diferença no direito. Porto Alegre: Livraria do Advogado, 2015.

SOUSA SANTOS, Boaventura de; MARQUES, Maria Manuel Leitão; PEDROSO, João. Os tribunais nas sociedades contemporâneas. Coimbra: Centro de Estudos Sociais, 1995.

STRECK, Lenio Luiz. Verdade e consenso: constituição, hermenêutica e teorias discursivas. São Paulo: Saraiva, 2011.

STRECK, Lenio Luiz. Do pamprincipiologismo à concepção hipossuficiente de princípio: dilemas da crise do direito. Revista de Informação Legislativa, a. 24, n. 194, abr./jun. 2012, p. 07-21. Disponível em: <https://www2.senado.leg.br/bdsf/bitstream/handle/id/496574/000952675.pdf?sequenc e=1>. Acesso em: 23 jan. 2017.

WARAT, Luis Alberto. Manifestos para uma ecologia do desejo. São Paulo: Ed. Acadêmica, 1990.

WARAT, Luis Alberto. A ciência jurídica e seus dois maridos. 2. ed. Santa Cruz do Sul: EDUNISC, 2000. 